\title{
PRZYCZYNEK DO IDENTYFIKACJI ŚREDNIOWIECZNEJ APARATURY DESTYLACYJNEJ W POLSCE
}

SŁowa KLuczowe: alembiki; zabytki archeologiczne; technologia destylacji

KEYWORDs: alembics; archaeological artefacts; distilling technology

\section{DESTYLACJA W POLSKICH STUDIACH NAD HISTORIĄ KULTURY MATERIALNEJ}

Czytając prace poświęcone kulturze materialnej czasów nowożytnych można natknąć się czasem na wzmianki o alembikach - dawnej aparaturze destylacyjnej. Podstawową wiadomością, jaką możemy wynieść z zapoznania się z tymi informacjami, jest sam fakt istnienia tego typu przedmiotów (Rutkowska, Zaryn 1955: 195; Więcek 2012: 91). Alembiki nie doczekały się w Polsce opracowania materiałowego, a historycy chemii oraz farmacji skupiają się na teoriach naukowych i zasadach łączenia składników a także wykorzystywaniu uzyskanych produktów (Bela 2010: 851-858). Techniczne aspekty procesu przeważnie, aczkolwiek nie zawsze (Klonder 1989: 26-30), umykają uwadze badaczy. Destylacja z parą wodną, choć znana w starożytności (Bugaj 1991: 55-57) i rozwijana we wczesnym średniowieczu w śródziemnomorskich ośrodkach naukowych, upowszechniona następnie w całej Europie Zachodniej, dopiero w czasach nowożytnych zdaje się być historycznie poświadczona dla ziem polskich (Roeske 1991: 107). Nie oznacza to oczywiście, że nie stosowano jej i wcześniej, zwłaszcza w aptekach miejskich oraz klasztornych, gdzie stanowiła przede wszystkim sposób pozyskiwania leczniczych destylatów ziołowych (Kuchowicz 1971: 667-668: Stępniewska 1961: 324).

Ziołolecznictwo w XVI i XVII wieku cieszyło się ogromną popularnością w związku z licznymi wznowieniami poczytnych receptariuszy i zielników, 
takich jak dzieła Stefana Falimirza, Marcina Siennika, Szymona Syreniusza (Keckowa 1978: 410-412). Szczególne uznanie zyskały thumaczone i wydawane w całej nowożytnej Europie „Sekrety” Aleksego z Piemontu (Aleksego Pedemontana...). Autorzy gromadzili w swych dziełach informacje $\mathrm{z}$ wielu zakresów nauki, opisując lecznicze walory rozmaitych surowców, sposoby przeprowadzania zabiegów medycznych i higienicznych, ale także metody otrzymywania lekarstw, kosmetyków oraz szeroko rozumianej chemii gospodarczej. Zasięg oddziaływania tych ksiagg był ogromny. W ten sposób upowszechnić się miały w Polsce również techniki destylacyjne, a wraz z nimi stosowne urządzenia (Roeske 1991: 107). W efekcie alembiki, choć niestanowiące dotychczas w Polsce przedmiotu osobnych studiów, uznawane bywają za nieodłączny element wyposażenia nowożytnego gospodarstwa domowego. Aparatura destylacyjna znalazła również zastosowanie w przemyśle. Od XVI wieku w coraz większej ilości miast oraz majątków wiejskich podejmowano działalność gorzelniczą (Kuchowicz 1971: 668-670; Klonder 1989: 39-41), ponadto proces destylacji był wykorzystywany m.in. przy pozyskiwaniu kwasów.

Jak na występowanie i zastosowanie aparatury destylacyjnej $\mathrm{w}$ dawnej Polsce należałoby patrzeć z perspektywy archeologii? Czy materiały pozyskane metodą wykopaliskową potwierdzają wyżej zarysowany obraz, a może przynoszą dodatkowe informacje? Na mapie europejskich znalezisk, sporządzonej przez N. Thomas'a, Polska stanowi białą plamę (Thomas 2009: 40, fig. 2). Choć trudno jest poszukiwać zabytków archeologicznych na odległość, zgodzić się trzeba, że polska literatura archeologiczna milczy na ten temat. Jednak znaleziska $\mathrm{z}$ terenu ziem polskich, aczkolwiek niepublikowane i (zapewne) nieliczne, istnieją. Brak zainteresowania, a co za tym idzie - publikacji, powoduje ich naukowy niebyt. Niniejszy szkic ma na celu przedstawienie zagadnienia $\mathrm{w}$ odniesieniu do „polskich” przykładów dawnej aparatury destylacyjnej, omówienie ich problematyki i zaprezentowanie możliwości identyfikacji tej grupy zabytków.

\section{„KLASYCZNA” ŚREDNIOWIECZNA APARATURA DESTYLACYJNA}

Większość destylatów opisywanych przez staropolskich uczonych pozyskiwano „tylko parzeniem pod alembikiem a wstępowanim pary wzgorę, potym sie z tey pary woda działa, a wycieka z Alembiku" (Falimirz 1534). W ten sposób przeprowadzano destylację z parą wodną, rozdzielając składniki o różnych temperaturach wrzenia i w efekcie pozyskując oczyszczony składnik lotny (Ziółkowski 1978: 328-331).

Podstawowym opracowaniem dla tego zagadnienia jest praca Stephena Moorhouse'a, poświęcona szklanym i ceramicznym zabytkom $\mathrm{z}$ terenu 
Wielkiej Brytanii (Moorhouse 1972: 79-121). Urządzenie destylacyjne składało się z trzech części składowych: naczynia, w którym doprowadzano destylowaną ciecz do wrzenia oraz alembiku - ustawianej na nim kopulastej pokrywy, w której następowało skroplenie pary i przekazanie jej do ostatniego elementu - odbieralnika (Ryc. 1). Ceramiczną aparaturę uważa za pochodną szklanej, co ma odbicie w typologicznych ustaleniach, jakie poczynił, a do których wypada się odwołać.

Skład szklanego zestawu do destylacji zasadniczo nie odbiegał od urządzeń wykonanych z innych surowców. Naczynie do odparowywania surowca (dalej będę używał określenia „odparowywacz”) przedstawiało formę butli o stosunkowo szerokiej szyjce, zaopatrzonej często w dookolną kryzę, na której opierał się od zewnątrz wyższy element - alembik. Otrzymywano ją poprzez odpowiednie ściśnięcie już uformowanej szyjki (Ryc. 2b). Przy odpowiednim dopasowaniu średnic otworów naczyń (zwłaszcza w przypadku alembiku, do nazwania dolnej jego krawędzi stosowniejszym niż „wylew” wydaje się określenie otwór), obywano się i bez kryzy (Moorhouse 1972: 92, fig 27)1.

Alembiki, ustawiane bezpośrednio na butli, były baniastymi naczyniami, w których tektonice dają się wyodrębnić trzy elementy. Podstawowy z nich to główna kopuła, w której opary chłodziły się od działającego z zewnątrz powietrza. Była ona integralna z kołnierzem, otwierającym ją od dołu; delikatnie wepchnięty w alembik, tworzył wewnątrz niego dookolną rynnę, do której spływał po ściankach kopuły skroplony już produkt destylacji. Z rynny dostawał się on do ostatniego elementu - charakterystycznej rurki, osobno zamontowanej w wyciętym na ten cel w załomie kopuły otworze. Skierowana do dołu odprowadzała destylat do odbieralnika, którym, jak przekonuje ikonografia, mogło być każde naczynie stołowe lub też specjalny flakon (Ryc. 2a).

Tego rodzaju aparaturę znamy w Polsce z jednego, dość nietypowego przedstawienia ikonograficznego. Stefan Falimirz (1534), a także powielający w dużej mierze jego treści oraz ilustracje Marcin Siennik (1568), w swoim zielni$\mathrm{ku}$, zgodnie z renesansowymi nurtami alchemii i farmacji, jakie zaprowadzał Paracelsus, przedstawia rozmaite surowce nieorganiczne. Lektura tych dzieł przekonuje, że doskonałym „rozdrabniaczem” kamienia nerkowego jest starte na proch szkło, podane do spożycia. Opis tego farmaceutyka, zgodny z arkanami sztuki pisania zielników, okrasza skromny drzeworyt, prezentujący wybór szklanych naczyń. Wśród przykładów szklanego złomu znajdują się wyżej przedstawione elementy zestawu do destylacji: butla z szeroką szyjką oraz

\footnotetext{
${ }^{1} \mathrm{Na}$ cytowanej rycinie wymienione rysunki przedstawiają: 13 - szyjka z kryzą; 14, 15, 19, 20, 21 - szyjki bez kryzy.
} 
alembik. Wyobrażony on został $\mathrm{w}$ charakterystyczny sposób, podkreślający obecność wewnętrznej rynny (Ryc. 3a). Podobnie aparatura ta ukazana została w datowanym na 1411 r. egzemplarzu Kriegsbuch z Wiednia (Ryc. 3b).

Ceramiczne odparowywacze $\mathrm{w}$ najprostszej formie określić można jako misy. Ich kształt dostosowany był do wyższych elementów aparatury, tak aby zapewnić całemu urządzeniu stabilność. Cechą wyróżniającą te naczynia jest zewnętrzna kryza, biegnąca dookolnie poniżej wylewu. Na niej to, podobnie jak u wyżej opisanych urządzeń ze szkła, opierał się alembik (Moorhouse 1972: 111-113). Inny, bardziej zdaniem S. Moorhouse'a pierwotny wariant odparowywacza to naczynie odpowiadające formą szklanym flaszom (Moonrhouse 1972: 104-105). Jego wysokość utrzymywała alembik w stosownej odległości od urządzenia ogrzewającego destylowane substancje, a także pozwalała wydzielić lotniejsze związki chemiczne.

Zabytki spełniające kryteria płytkich odparowywaczy - ceramiczne misy z kryzą - spotykane są w materiałach z polskich wykopalisk. Przykładów dostarczyły badania na terenie grodziska w Mymoniu, pow. Krosno (Cabalska 1975: 326). Zalicza się do nich fragment misy wypalonej $w$ atmosferze utleniającej o średnicy dna $23 \mathrm{~cm}$ i $27 \mathrm{~cm}$ wylewu oraz ok. $6 \mathrm{~cm}$ wysokości (Ryc. 4) ${ }^{2}$. Naczynie to po zewnętrznej stronie posiadało płaską, delikatnie uniesioną kryzę, biegnącą ok. 1,5 cm poniżej krawędzi wylewu i mającą ok. $1 \mathrm{~cm}$ szerokości. Zostało pozyskane w trakcie eksploracji tzw. „Jamy 7”, stanowiącej pozostałość częściowo zagłębionego w ziemię, niewielkiego budynku o centralnie zlokalizowanym palenisku otwartym (Cabalska 1975: 327 - ryc. 10a, 329). Kolejny fragment naczynia o wysokości $6 \mathrm{~cm}$ i niepodanej średnicy miał lekko podniesioną kryzę o szerokości ok. $1,5 \mathrm{~cm}$, umieszczoną ok. $1,8 \mathrm{~cm}$ poniżej krawędzi wylewu. Został wypalony w atmosferze utleniającej i znajdował się w zasypisku „Jamy 8” (Cabalska 1975: 336). Jeszcze inny fragment wylewu, pochodzący z wnętrza chaty zadokumentowanej jako „Jama 4”, cechowała kryza mniejsza i opuszczona, teoretycznie mniej przydatna. Prezentowane misy zostały wykonane z plastycznej gliny schudzonej drobnoziarnistym piaskiem, wypalone $\mathrm{w}$ atmosferze utleniającej oraz pokryte po wewnętrznej stronie jasnozielonym szkliwem. Naczynia te cechowały się znacznym zmniejszeniem grubości ścianek powyżej kryzy, wynikającym zapewne z metody formowania tego elementu poprzez rozdwojenie krawędzi wylewu i odchylenia zewnętrznej jego części. Znaczna średnica wylewu, w połączeniu z niewielką wysokością mis, zapewniała dużą powierzchnię parowania. Dzięki obecności kryzy (autorka, uznając ją

\footnotetext{
${ }^{2}$ Grodzisko w Mymoniu, w jamie 9 ,fragmenty misy toczonej z zieloną polewą (identyczny jak ryc. 10a)".
} 
za plastyczny motyw zdobniczy, używa określenia „żeberka”) możliwym było nadstawianie na mymońskich misach kolejnych elementów aparatury destylacyjnej, tak jak ma to miejsce w przypadku urządzeń opisanych przez S. Moorhouse'a. Wobec braku pozostałych elementów aparatury wśród reszty opublikowanych zabytków z grodziska w Mymoniu, trudno jednoznacznie i kategorycznie stwierdzić, czy owe misy pełniły rozważane tu funkcje. Pod względem technologicznym takie ich wykorzystanie było jednak możliwe.

Ceramiczne alembiki kształtem zbliżone były do swoich szklanych odpowiedników (Moorhouse 1972: 81). Na podstawie zróżnicowania kształtu rynien, S. Moorhouse wydzielił dwa typy. Typ I stanowi prostą kopię szablonowej formy szklanego alembiku, natomiast Typ II został skrócony o kołnierz; rynnę tworzono, zawijając do wewnątrz krawędź otworu naczynia. Prawdopodobnie alembiki typu drugiego łączono bezpośrednio z odparowywaczami-misami (Moorhouse 1972: 107-109), podczas gdy typ pierwszy, powielając schemat urządzeń wykonywanych ze szkła, ustawiano na wyższych podstawach lub ceramicznych flaszach. N. Thomas do typologii tej wprowadził Typ III. Rynny alembików należących do Typów I i II powstawały poprzez odpowiednie obrobienie czerepu naczynia i ich obecność ma odbicie w zewnętrznym ukształtowaniu alembiku. W Typie III nie są one pochodną zewnętrznego ukształtowania tego urządzenia i znajdują się powyżej prosto ukształtowanego otworu (Ryc. 5) (Thomas 2009: 41-42).

O znajomości alembików II typu w Polsce świadczy drzeworyt ze znanego nam już herbarza Stefana Falimirza, otwierający księgę poświęconą destylacji oraz jej produktom. Przedstawia on wnętrze kuchni, w której grupa kobiet obsługuje ustawione na piecu zestawy destylacyjne (Ryc. 6). Oczywiście, trudno określić, z jakiego surowca wykonane zostały przedstawione aparaty. Nieznany dotychczas zabytek ceramicznego alembiku z zamku w Pucku, niedający się umieścić $\mathrm{w}$ wyżej przytoczonych propozycjach typologicznych, zostanie omówiony w kolejnym podrozdziale jako służący do bardziej zaawansowanych metod destylacyjnych. Być może w przyszłości dla podobnych mu znalezisk wydzielony zostanie osobny typ, wymagać to jednak będzie wnikliwej, aktualizującej obserwacji przemian w technikach destylacyjnych.

\section{W STRONE NOWOŻYTNEJ APARATURY DESTYLACYJNEJ}

Zygmunt Gloger w pierwszym tomie Encyklopedii Staropolskiej pisze o alembiku, że jest to „naczynie miedziane, które jeszcze w pierwszej połowie XIX wieku znajdowało się w każdym dworze szlacheckim, służąc gospody- 
niom do oczyszczania gorzałki, a niekiedy i innych płynów. Alembik składał się z trzech części: kotła, czapki i dwóch rur. W kociół, postawiony na ognisku i przykryty czapką miedzianą, nalewała się ciecz, przeznaczona do dystylacyi, która następowała przez parowanie do czapki i skraplanie się w rurach, idących z czapki pochyło na dół przez naczynie z zimną wodą. $Z$ rur tych kapał płyn już oczyszczony do podstawionego pod ich dolne końce zbiornika. Wódka $\mathrm{w}$ ten sposób oczyszczona zwana była alembikówką i służyła na nalewki i do zapraw rozmaitych" (Gloger 1972: 39).

Opis ten dobrze oddaje charakterystykę zabytków należących do zbiorów Muzeum Farmacji Uniwersytetu Jagiellońskiego, datowanych na czasy nowożytne (Bela 2013: 203-214). Odpowiada on również opisom urządzeń destylacyjnych, jakie odnajdujemy w spisach inwentarzowych z XVIIXVIII w. Źródła te w pewien sposób rozróżniają aparaturę destylacyjną na domową oraz przeznaczoną do przemysłowej produkcji alkoholu. Wyposażenie gorzelni stanowił więc ,garniec gorzałczany z rurami i pokrywką" (Rusiński 1955: 173. 198), uzupełniany przez „rurnicę”, względnie „beczkę do gorzałki o 2 rurach" (Rusiński 1955: 50-52). Mamy tu do czynienia z wyprowadzonym poza alembik systemem chłodzącym. Rurnica, czyli chłodnica (Klonder 1989: 26), stanowiła przedłużenie rurki alembiku, zwiększające przestrzeń chłodzenia i wydłużające drogę, jaką pokonać musiała unosząca się para. Chłodzenie intensyfikowało umieszczenie rurnicy $\mathrm{w}$ beczce $\mathrm{z}$ woda; kilkukrotne zawinięcie przewodu wewnattrz tego zbiornika dodatkowo podnosiło walory chłodzące (Roeske 1991: 108-109). Potrzebę rozbudowania systemu chłodzącego dostrzegano również w średniowieczu. Ilustracja z Kriegsbuch przedstawia urządzenie destylacyjne pozbawione rurki odchodzącej w bok, jak miałoby to miejsce przy „klasycznym” alembiku, lecz posiadające otwór w górnej części czerepu (Ryc. 7a). Zamontowano w nim długą, giętką rurkę, przerzuconą przez podwieszony pod sufitem drążek i umocowaną drugim końcem w odbieralniku. Inna ilustracja $\mathrm{z}$ tego samego dzieła pokazuje już aparaturę bardzo podobną do wyżej opisanej - rurka wychodząca z boku alembiku dostaje się do klepkowego naczynia $\mathrm{z}$ woda, by następnie, przez boczny otwór w dolnej jego partii, dotrzeć do odbieralnika (Ryc. 7b). Tego rodzaju zabiegi nie były więc w czasach nowożytnych żadną nowością i stosowano je już w XV wieku. Być może we wcześniejszym okresie częściej stosowana była prosta, niewykazująca tendencji do spiralnego zawinięcia się forma rurnicy. Schematy takiego systemu w rozwiniętej już postaci często drukowano w postaci grafik od XVI wieku. Na barwnym drzeworycie z wydanego w 1572 r. dzieła Adama Loniceriego (Kräuter Buch und künstliche Conterfeyungen sammt der Kunst 
$z u$ Destillieren) widać, że rurki dwóch stojących w jednej linii alembików skierowane są ku dołowi, w stronę beczki (Ryc. 7c). Takie rozwiązanie pozwalało na użycie pojedynczej, dodatkowej rurnicy, niezałamującej się na poszczególnych odcinkach, wydaje się zatem najprostszą formą rozwiniętego przewodu destylacyjnego. W tym samym starodruku znajdują się również bardziej złożone rurnice, przybierające m.in. postać spirali.

Przedstawiona powyżej metoda destylowania stanowi krok naprzód w stosunku do skraplania pary w alembiku i odprowadzania z niego destylatu poprzez rynnę i rurkę. Alembik łączący w sobie szereg funkcji nie był najdoskonalszą chłodnicą i wraz z destylatem, przez rurkę ulatywały również opary. Wyprowadzenie $\mathrm{z}$ alembiku funkcji skraplającej, wydhużenie rurki i dodatkowe jej chłodzenie pozwoliło uzyskać większą wydajność aparatury. Upowszechnienie takiej metody destylacji przypadło na okres nowożytny i było dalej rozwijane, aż do uzyskania obecnej postaci.

W tym właśnie miejscu warto przytoczyć ciekawe znalezisko z fosy zamku w Pucku (wykop 36, fragmenty poch. z warstw 18, 23, 24 i 26), datowane na II połowę XV wieku (Ryc. 8). Chodzi o wspominany już wcześniej, niepublikowany dotychczas alembik ${ }^{3}$, za którego udostępnienie wraz z udzieleniem potrzebnych informacji serdecznie dziękuję p. mgr Martynie Milewskiej z Instytutu Archeologii Uniwersytetu Warszawskiego. Urządzenie wykonane zostało z gliny żelazistej oraz wypalone w atmosferze utleniającej i pokryte od wewnątrz przezroczysta, żółtą polewą. Zachowana wysokość wynosi $29 \mathrm{~cm}$, przy średnicy dolnego otworu $22 \mathrm{~cm}$ i średniej grubości ścianek ok. $0,6 \mathrm{~cm}$. Prawdopodobnie stożek alembiku zwieńczony był uchwytem w formie gałki. Egzemplarz ten nie posiadał po wewnętrznej stronie rynny, znanej z alembików odprowadzających gotowy destylat. Wylew ukształtowany został natomiast na kształt wrębu, pozwalającego ustawić alembik na misie o prostym wylewie z grubą krawędzią. Do wykonanego tuż nad wrębem otworu średnicy $1,7 \mathrm{~cm}$ doklejono od zewnątrz rurkę długości ok. $8,3 \mathrm{~cm}$ oraz grubości ścianek $0,6 \mathrm{~cm}$. Średnica jej otworu od strony wnętrza alembiku wynosi $1,3 \mathrm{~cm}$, podczas gdy zewnętrzny otwór ma już $2 \mathrm{~cm}$ średnicy (średnica wylewu rurki $2,8 \mathrm{~cm}$ - nastąpiło ścienienie krawędzi). Rurka skierowana jest do dołu i sięga swym końcem poniżej dolnej krawędzi alembiku.

W alembiku z Pucka uwagę zwracają dwa elementy konstrukcyjne, zdające się świadczyć o włączeniu go w zestaw destylacyjny z systemem zewnętrznego chłodzenia. Brak wewnętrznej rynny pokazuje, że nie zachodziło w nim skrapla-

\footnotetext{
${ }^{3}$ Już po napisaniu tego artykułu, ukazała się publikacja książkowa (Kruppé, Milewska 2014) poświęcona badaniom zamku w Pucku, w której zamieszczono ilustracje omawianego zabytku.
} 
nie. Rozszerzająca się rurka to prawdopodobnie efekt mocowania jej do alembiku, lecz budzi ona skojarzenia z tulejkami trójnóżek, w które wsuwane były drewniane trzonki. Być może do wnętrza rurki omawianego urządzenia wkładano koniec rurki samodzielnej, np. miedzianej, odprowadzającej parę w kierunku kolejnych elementów zestawu destylacyjnego. Skierowanie jej ku dołowi ułatwiało wprowadzenie rurnicy do naczynia $\mathrm{z}$ wodą, ustawionego poniżej alembiku. Opary w dalszych częściach składowych aparatury ulegały skropleniu i w ostatecznej już postaci spływały do odbieralnika.

\section{URZĄDZENIA TOWARZYSZĄCE ALEMBIKOM}

Użytkowanie aparatury destylacyjnej wymagało wykorzystywania szeregu przyrządów oraz podejmowania dodatkowych zabiegów. Na drzeworycie z zielnika Stefana Falimirza (Ryc. 6) można dostrzec miech, akcesoria do rozdrabniania i przenoszenia ziół oraz urządzenia ogniowe. Z kuchennego pieca, na którym ustawione zostały alembiki, wysypują się węgle, przenoszone do specjalnych, ustawionych pod alembikami palenisk. Brak otworków w ich ściankach (poza czeluścią) każe zastanowić się nad funkcjonalnością. Eksperymentalna próba wykorzystania ceramicznej rekonstrukcji urządzenia o zachowanych proporcjach zakończyła się mechanicznym uszkodzeniem wskutek wysokiej temperatury, jaka wytworzyła się w jego wnętrzu. Problem ten nie wystąpił przy zastosowaniu palenisk z dodatkowymi otworami, które pozwoliły zresztą na utrzymanie $\mathrm{w}$ środku ognia. Ceramiczne fajerki zaopatrzone w liczne otwory wentylacyjne i łączone właśnie z aparaturą do destylacji znane są m.in. z Wielkiej Brytanii (Moorhouse 1972: 104, 113-114). Jako palenisko laboratoryjne służyć mogły również zwykłe, płaskie misy na żar, takie jak np. zabytki z łaźni klasztoru kanoników regularnych w Trzemesznie (Sulkowska-Tuszyńska 2004: 198, ryc.12). Odparowywacze można było również ogrzewać bezpośrednio przy palenisku kuchennym. Taka strategia prowadziła nierzadko do przypalenia destylowanych substancji, co niweczyło cały proces. Aby uniknąć tego nieszczęścia, dość wcześnie wprowadzona została kạpiel wodna, polegająca na pośrednim ogrzewaniu odparowywacza poprzez umieszczenie go w naczyniu z gotującą się wodą. Wprowadzenie tego rozwiązania tradycyjnie przypisywano Marii Żydówce z Aleksandrii, alchemiczce żyjącej w III wieku naszej ery - stąd zwano je balneum mariae, „kappiel Mariej” (Bela 1999: 142-143). Na tym koncepcie opierał się opisany w XI w. przez Abulcasisa wynalazek specjalnego pieca do destylacji, athanora (Ryc. 7c) (Bela 1999: 144; Jagla 2013: 548-550). Specjalne piece zintegrowane $\mathrm{z}$ aparaturą destylacyjną wykorzystywano przy 
produkcji gorzałki - inwentarskie opisy gorzelni pełne są sformułowań takich jak „W piecu murowany garniec gorzałczany, miedziany" (Nawrocki, Wisłocki 1961: 188-189). Zastosowanie destylacji na przemysłową skalę wiązało się z koniecznością wykonania systemu doprowadzającego wodę i całej stosownej infrastruktury ${ }^{4}$. Te urządzenia, znane dobrze ze źródeł pisanych oraz ikonograficznych, zdają się być wdzięcznym tematem do osobnych rozważań.

Interesujące z punktu widzenia badacza poszukującego pozostałości samych alembików są różnego rodzaju ślady widoczne na ich ściankach. Przypalone resztki ziół wewnątrz odparowywaczy to tylko niektóre pozostałości, z jakimi można się spotkać. Na łączeniach elementów zestawu do destylacji powstawały przerwy, którymi uchodziła para. Aby je skutecznie uszczelnić, wypracowano recepturę na specjalną „glinę alchemiczną”, nietracącą swych walorów pod wpływem działania wysokiej temperatury. W tym celu mieszano glinę z wełnianymi wyczeskami, popiołem, drobinami tłuczonej cegły oraz końskim łajnem, a następnie dbano o trzymanie tego produktu w chłodzie i wilgoci, „bo raz uschnięta wniwecz pójdzie” (Bela 1999: 225). Taki dobór surowców wydaje się rozwiązaniem skutecznym - thuczona cegła podnosiła ogniotrwałość, a wyczeski zapewniały substancji włóknistą strukturę, powstrzymującą rozpękanie. Gnój koński prawdopodobnie uzupełniał wyczeski dzięki zawartości drobno przemielonej sieczki. Tak uzyskaną ,glinę" umieszczano w przestrzeni między alembikiem a odparowywaczem, w miejscach styku rurek bardziej złożonych zestawów, a także oklejano nią z zewnątrz różnego rodzaju delikatne urządzenia (np. szklaną aparaturę destylacyjną) narażone podczas używania na niszczące działanie ognia. Gliną oblepiano również aparaturę do destylacji gorzałki (Klonder 1989: 27).

\section{ZAKOŃCZENIE}

Zamek krzyżacki w Pucku, wzniesiony pod koniec XIV wieku, posiadał bujną historię. Pierwotnie stanowił on siedzibę urzędu rybickiego, natomiast w II połowie XV stulecia, a więc w okresie, na jaki datuje się opisany wyżej alembik, przechodził z rąk do rąk, pełniąc docelowo funkcję siedziby starosty puckiego, lecz okazjonalnie znajdował się w zastawie mieszczan gdańskich, zbiegłego króla Szwecji, a w 1460 r. na 4 lata wrócili do niego Krzyżacy. W 1464 r. odbili go Gdańszczanie, zaś w 1468 r. zajął go wreszcie wojewoda pomorski - Otton Marchwic. Nie na długo jednak, gdyż w latach 1491-1545

\footnotetext{
${ }^{4} \mathrm{~W}$ interesujący sposób urządzenia towarzyszące nowożytnym gorzelniom scharakteryzował ostatnio Pietrzak (2013: 69-99); porównaj też (Klonder 1989: 24-28).
} 
ponownie zastawiony, znajdował się pucki zamek pod opieką gdańskiej rady miejskiej (Milewska, Kruppé 1997: 43-45). Przez cały ten czas funkcjonowała zamkowa kuchnia, znajdująca się na parterze jego kamienicy. Do budynku przylegała fosa, w obrębie której zaobserwowano skupisko odpadków związanych z użytkowaniem kuchni (obszar ten określony został jako „śmietnisko kuchenne"), prawdopodobnie wyrzucanych z niej przez okno (Milewska, Kruppé 2004: 233-235). Na obrzeżach tego właśnie śmietniska odnaleziono omawiany powyżej alembik. Problematyka funkcjonalności jam eksplorowanych na grodzisku w Mymoniu nie pozwala już na tak wdzięczne interpretacje, jednak obecność w zawierającej najbardziej „spójne” wypełnisko Jamie 7 kości zwierzęcych wskazuje na kuchenne funkcje znajdującego się tam paleniska (Siennik 1568). Późnośredniowieczna faza tego grodziska wiązana jest z rycerską siedzibą powstałą już po przyłączeniu tego terenu do Korony (Kotowicz 2007: 54-56, 63-65); Kuchnie i inne niezależne zabudowania gospodarcze spotyka się sporadycznie w obrębie rozleglejszych gródków rycerskich (Kajzer 1989/1990: 241-290).

Upowszechnioną w XIII wieku (Thomas 2009: 37-38) destylację znano i stosowano w średniowiecznych, a także nowożytnych kuchniach, klasztorach, aptekach oraz szeroko pojętych pracowniach chemicznych, działających nieraz przy obiektach przemysłowych, np. metalurgicznych (Moorhouse 1972: 86-87). Tym samym długa jest lista stanowisk, na których potencjalnie należy liczyć się z możliwością wystapienia alembików lub stosownych akcesoriów. Inwentarze szlacheckie oraz mieszczańskie z XVI-XVIII w. stosunkowo często wymieniają cynowe i miedziane urządzenia destylacyjne, pomijając $\mathrm{w}$ ogóle ceramikę (Nawrocki, Wisłocki 1961: 163, 205, 223, 230, 335, 378, 410, 458-459; Burszta, Łuczak 1965: 102, 110, 112, 165, 167, 218, 227, 235, 236, 254, 273, 278, 279, 281, 282, 296, 304). Szanse odnalezienia takich alembików są oczywiście o wiele mniejsze, niż wykonanych z surowca łatwo tłukącego i mniej zdatnego do wtórnego wykorzystania. Specyfika zabytków szklanych i ceramicznych powoduje, że możliwości zinterpretowania ich fragmentów jako urządzenia służące do destylacji są ograniczone. Istnieją oczywiście charakterystyczne fragmenty, które powinny budzić jasne skojarzenia; należą do nich zwłaszcza wylewy odparowywaczy wyposażone w dookolne kryzy zewnętrzne oraz wewnętrzne rynny odprowadzające destylat. Rzucające się w oczy rury i rurki, znajdywane fragmentarycznie, bez innych charakterystycznych części naczynia, nie mogą być bezkrytycznie wiązane $\mathrm{z}$ aparaturą destylacyjną. Forma alembików odprowadzających rurką gotowy destylat zasadniczo 
pozostała niezmienna po XVIII stulecie (Thomas 2009: 40), zatem walory datujące ma raczej technologia, $\mathrm{w}$ jakiej zostały wykonane oraz kontekst znaleziska.

Wielofunkcyjność naczyń szklanych, ceramicznych oraz metalowych sprawia, że do destylacji można było używać również i innych naczyń, niż specjalnie do tego celu przeznaczone alembiki. Konwie z rurkami, zwykłe butelki, a także garnki, dzbany i misy miały wiele zastosowań, nie zawsze czytelnych z dzisiejszej perspektywy. Funkcji destylacyjnej pewni być możemy jedynie w przypadku naczyń specjalnie do tego przeznaczonych, posiadających charakterystyczną formę i w związku z tym łatwych do zidentyfikowania. Warto w tym miejscu wyrazić nadzieję, że niniejszy artykuł przyniesie zamierzony efekt i ułatwi rozpoznawanie znalezisk tego rodzaju.

Zagadnienie aparatury destylacyjnej pozyskiwanej wskutek prac archeologicznych potwierdza tezę, że archeologia zarówno uzupełnia, jak i weryfikuje ustalenia historyków. Jak się okazuje, dotyczy to również badaczy zajmujących się dziejami nauk ścisłych i przyrodniczych. Niedostatek źródeł pisanych dla terenów ziem polskich sugerował nieznajomość technik destylacyjnych przed pojawieniem się nowożytnych pism drukowanych. Być może w średniowiecznej Polsce proces destylacji był mniej popularny, badania archeologiczne dostarczają jednak dowodów na jego ówczesną znajomość. Źródła archeologiczne wnoszą do rozważań historyków chemii i farmacji nowe przesłanki do określenia chronologii przemian w przemyśle chemicznym. Konteksty znalezisk pozwalają wnioskować o zastosowaniu poszczególnych zabiegów oraz ich społecznych uwarunkowaniach. Szczególnie interesujący pod względem spojrzenia na rozwój technologii destylacji wydaje się unikatowy alembik z zamku w Pucku. Być może kolejne znaleziska przyniosą dalsze spostrzeżenia i wpłyną korzystnie zarówno na wiedzę archeologów o asortymencie naczyń kuchennych oraz przemysłowych, jak i na rozwój gałęzi nauki, jaką stanowi historia chemii.

mgr Michał Szymański

Uniwersytet Łódzki

Wydział Filozoficzno-Historyczny

Instytut Archeologii

ul. Uniwersytecka 3

90-137 Łódź 


\section{Bibliografia}

Źródła

Aleksego Pedemontana „, Tajemnice księgi ośmiory o tajemnych a skrytych lekarstwiech, przy czym dosyć misternych a trafnych rzeczy i doświadczonych mieć będziesz”, tłum. M. Siennik, [w:] M. Siennik, Herbarz, to iest ziót tutecznych, postronnych y zamorskich opisanie [...]: teraz nowo wedle Herbarzow dzisieyszego wieku, y innych zacnych medykow, poprawiony: przydano Alexego Pedemontana Księgi ośmiory, o taiemnych a skrytych lekarstwiech, Kraków 1568, skan udostępniony przez: Polska Biblioteka Internetowa (http://pbi.edu.pl/book reader.php? $\mathrm{p}=52521 \& \mathrm{~s}=1)$, (dostęp: 30 stycznia 2014).

Falimirz S. (1534), O ziołach i mocy ich, Kraków, skan udostępniony przez: Dolnośląska Biblioteka Cyfrowa (http://www.dbc.wroc.pl/dlibra/docmetadata?id=2228), (dostęp: 30 stycznia 2014).

Hartlieb J. (1411), Kriegsbuch, Österreichische Nationalbibliothek, Cod. 3069.

Lonitzer A. (1564), Kreuterbuch, Frankfurt a/Men, (skan udostępniny przez Bayerische Staatsbibliothek).

Siennik M. (1568), Herbarz, to jest ziót tutecznych, postronnych $i$ zamorskich opisanie, [w:] M. Siennik, Herbarz, to iest ziół tutecznych, postronnych y zamorskich opisanie [...]: teraz nowo wedle Herbarzow dzisieyszego wieku, y innych zacnych medykow, poprawiony: przydano Alexego Pedemontana Księgi ośmiory, o taiemnych a skrytych lekarstwiech, Kraków 1568, skan udostępniony przez: Polska Biblioteka Internetowa (http://pbi.edu.pl/book_ reader.php? $\mathrm{p}=52521 \& \mathrm{~s}=1)$, (dostęp: 30 stycznia 2014 ).

Opracowania

Bela Z. (1999), Aleksego Pedemontana Tajemnice. Monografia, Medycyna Praktyczna, Kraków.

Bela Z. (2010), Sposoby preparowania tzw. wódek w Herbarzu Polskim Marcina Siennika, „Farmacja Polska”, R LXVI, nr 12, s. 851-858.

Bela Z. (2013), O starożytnych antidotach, złotych pigułkach $i$ innych sprawach zwiqzanych z historia farmacji, Medycyna Praktyczna, Kraków.

Bugaj R. (1991), Hermetyzm, Ossolineum, Wrocław.

Burszta J., Łuczak Cz. oprac. (1965), Inwentarze mieszczańskie z wieku XVIII z ksiag miejskich i grodzkich Poznania, t. II (1759-1793), UAM, Poznań.

Cabalska M. (1975), Grodzisko w Mymoniu, pow. Krosno w świetle badań archeologicznych, „Materiały starożytne i wczesnośredniowieczne”, t. III, s. 321-339.

Gloger Z. (1972), Encyklopedia Staropolska, t. I, Warszawa.

Jagla J. (2013), Apteka jako alegoryczny obraz świata. XVII-wieczne malowidła z klasztoru pijarów w Rzeszowie, ,Studia Ełckie”, t. 15, nr 2, s. 541-562. 
Kajzer L. (1989/1990), Średniowieczny drewniany dwór obronny w Orłowie nad Bzura, „Slavia Antiqua” t. XXXII, s. 241-290.

Keckowa A. (1978), Higiena i zdrowotność, [w:] Historia Kultury Materialnej Polski $w$ zarysie, t. III, red. A. Keckowa, D. Molenda, Ossolineum, Wrocław, s. $395-416$.

Klonder A. (1989), Napoje fermentacyjne w Prusach Królewskich w XVI-XVII wieku (Produkcja - Import-Konsumpcja), Ossolineum, Wrocław.

Kotowicz P. N. (2007), Problematyka „Zamczyska” w Mymoniu w świetle zabytków archeologicznych ze zbiorów Muzeum Historycznego w Sanoku, [w:] Seminarium Trepczańskie, red. W. Banach, E. Kasprzak, P. N. Kotowicz, Muzeum Historyczne, Sanok, s. 51-67.

Kruppé J. (1981), Garncarstwo późnośredniowieczne w Polsce, Ossolineum, Wrocław.

Kruppé J., Milewska M. (2014), Dzieje zamku w Pucku, Instytut Archeologii UW, Fundacja Przyjaciół IA UW, Warszawa.

Kuchowicz Z. (1971), Uwagi o konsumpcji produktów destylacji alkoholowej w Polsce w XVI w., „Kwartalnik Historii Kultury Materialnej” R XIX, nr 4, s. $667-678$.

Milewska M., Kruppé J. (1997), Zamek pucki w badaniach archeologicznych 1991-1996, „Kwartalnik Historii Kultury Materialnej”, R XLV, nr 1, s. 43-59

Milewska M., Kruppé J. (2004), Wyposażenie gospodarstwa domowego na zamku krzyżackim w Pucku, „Archaeologia Historica Polona”, t. XIV, s. 233-244.

Milewska M., Kruppé J. (2014), Dzieje zamku w Pucku, Warszawa

Moorhouse S. (1972), Medieval Distilling-Apparatus of Glass and Pottery, „Medieval Archaeology", vol. 16, s. 79-121.

Nawrocki S., Wisłocki J. oprac. (1961) Inwentarze mieszczańskie z lat 1528-1635 z ksiag miejskich Poznania, PWN, Poznań.

Pietrzak J. (2013), Nowożytne budownictwo przemystowe $w$ dobrach biskupich na Mazowszu, Instytut Archeologii UŁ, Łódź.

Roeske W. (1991), Polskie apteki, Ossolineum, Wrocław.

Rusiński W. wyd. (1955), Inwentarze dóbr szlacheckich powiatu kaliskiego. T. 1, OdXVI do połowy XVIII w., Ossolineum, Wydawnictwo PAN, Wrocław.

Rutkowska J., Żaryn S. (1955), Wnętrze kamienicy mieszczańskiej, [w:] Szkice Staromiejskie, O. Puciaty, H. Szwankowska, E. Szwankowski, S. Żaryn (red.), Wydawnictwo Sztuka, Warszawa, s. 175-198.

Stępniewska B. (1961), Dawne apteczki domowe w Polsce, „Farmacja Polska”, R XVI, nr 15-16, s. 322-325.

Sulkowska-Tuszyńska K. (2004), Wyposażenie łaźni klasztoru kanoników regularnych w Trzemesznie, „Archaeologia Historica Polona”, t. 14, s. 189-210. 
Thomas N. (2009), L'alambic dans la cuisine?, [in:] La cuisine et la table dans la France de la fin du Moyen Age, eds. F. Ravoire, A. Dietrich, Publications du CRAHM, Caen, s. 35-50.

Więcek E. (2012), Kuchnia i jadalnia zamożnych mieszkańców XVIII-wiecznej Warszawy, „Warszawskie Materiały Archeologiczne”, t. 10, s. 88-109.

Ziółkowski Z. (1978), Destylacja i rektyfikacja w przemyśle chemicznym, wyd. 2, WNT, Warszawa.

SuMmary

\section{AN INTRODUCTION TO IDENTIFICATION OF MEDIAEVAL DISTILLING-APPARATUS IN POLAND}

Although alembics, erstwhile distilling-apparatus, are deeply rooted in Polish traditional culture, they have not been yet analysed separately. Ceramic and glass alembics, rarely being discovered during excavations within Poland, are also seldom published. Therefore using Western European studies seems to be necessary to amend that state of being. The case study on distilling-apparatus from France and Great Britain, which was used in the article, has been compiled by S. Moorhouse and N. Thomas. They presented morphologic traits of the devices: vaporizer - distilling-base or cucurbit used for heating the raw material, and alembic - a still-head with collecting-channel and spout. The authors also described industrial, kitchen and alchemical use of the devices. Based on the morphological traits, 3 types of ceramic and glass alembics were established, and presented in the article.

Article uses findings already published, focuses on preliminary issues and is an attempt on introducing the reader to the matter of former distilling-apparatus. Amongst sources published in Poland one should distinguish graphics from Marcin Siennik's Herbarz, to iest ziót tutecznych y zamorskich opisanie, Polish $16^{\text {th }}$ century herbarium, fragments of pottery distilling-base from the knight's stronghold from Mymon, Podkarpackie Voivodeship and alembic from castle in Puck, Pomeranian Voivodeship. The latter, although ceramic, represents advanced type of distilling-apparatus with an external cooling system - removable pipe, placed in the barrel with water.

Amongst instalations associated with alembics, one should mention special furnaces (athanors), ember dispensers and receivers for distillate. Another fact worth mentioning is that distilling-apparatus could be luted with a special alchemical clay, recipe of which is known from Renaissance herbarium by Marcin Siennik. Alchemical utensils were frequently placed in a separate room, especially in pharmacies and distilleries.

Distilling-apparatus, artefacts heretofore neglected in Poland, could help in development of studies in the history of chemistry and complement an image of cultural space in pre-industrial Central Europe. 


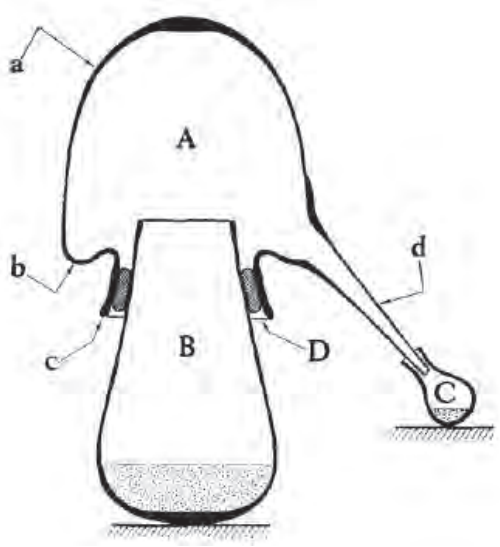

Ryc. 1. Szklana aparatura destylacyjna: A - alembik; a - kopuła-chłodnica, b - rynna, c - kołnierz, d - rurka odprowadzająca, B - odparowywacz, C - odbieralnik, D - uszczelnienie "gliną alchemiczną"

(Źródło: Moorhouse 1972: 88, fig. 25)

a

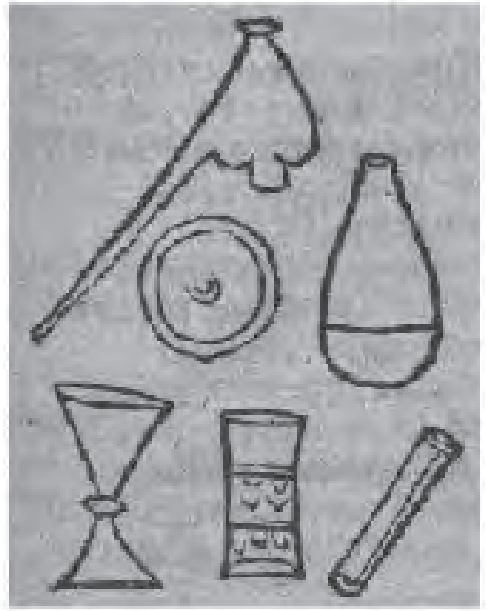

a

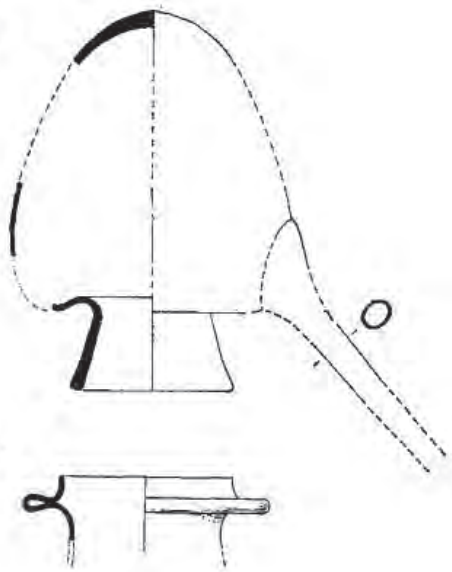

Ryc. 2. Elementy szklanej aparatury destylacyjnej: a - alembik z klasztoru w Selborn, b-szyjka odparowywacza z opactwa w Pontefract

(Źródło: Moorhouse 1972: 92, fig. 27:13, 100, fig. 30:4)

b

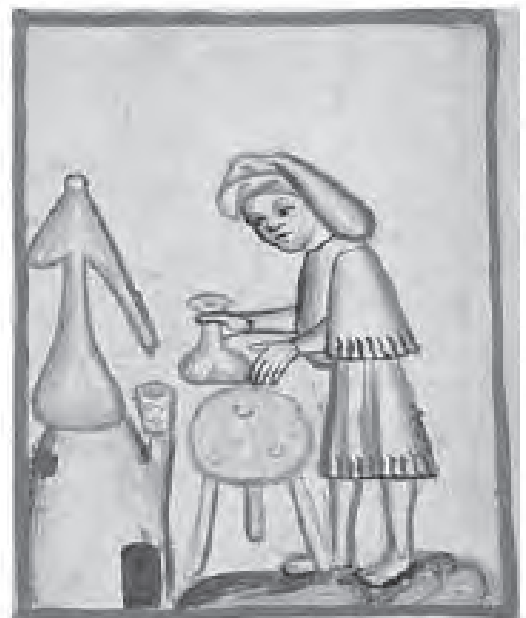

Ryc. 3. Przedstawienia ikonograficzne szklanej aparatury destylacyjnej: a - szklana aparatura w użyciu, b - polskie przedstawienie szklanego alembika wraz z odparowywaczem (Źródło: a - Hartlieb 1411; b - Falimirz 1534) 


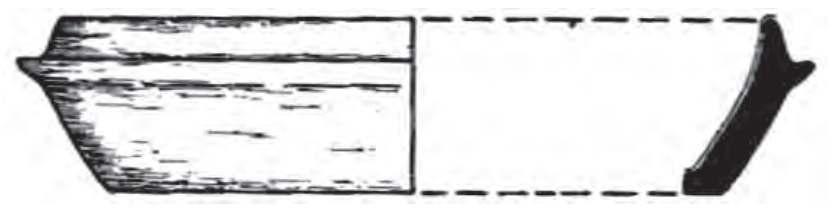

Ryc. 4. Ceramiczna ,misa z żeberkiem" - odparowywacz z grodziska w Mymoniu (Źródło: Kruppé 1981: tab. 76:3 )
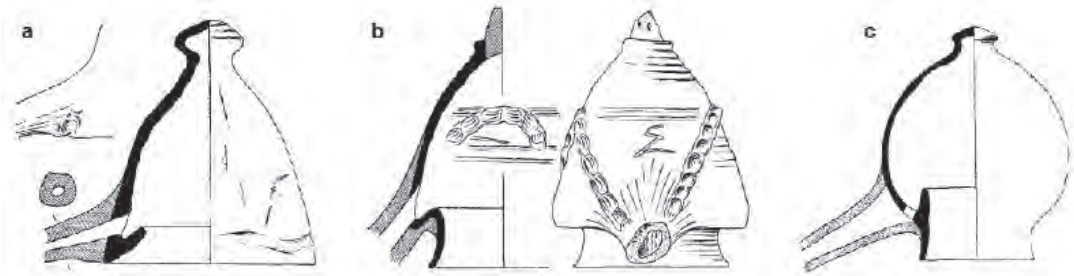

d

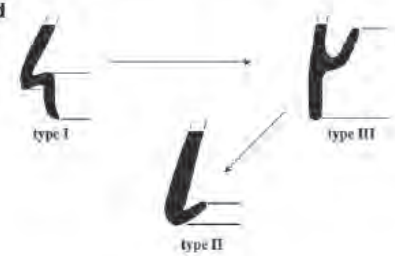

Ryc. 5. Typologia ceramicznych alembików: a - alembik typu II z Friary Lane w Nottingham, b - alembik typu I z Fenchurch Street w Londynie, c - alembik typu III z Surrey Street w Londynie, d - typologia alembików S. Moorhouse'a i N. Thomas'a (Źródło: a - c Moorhouse 1972: 108, fig. 31:1, 4, 5; d-Thomas 2009: 41, fig. 4)

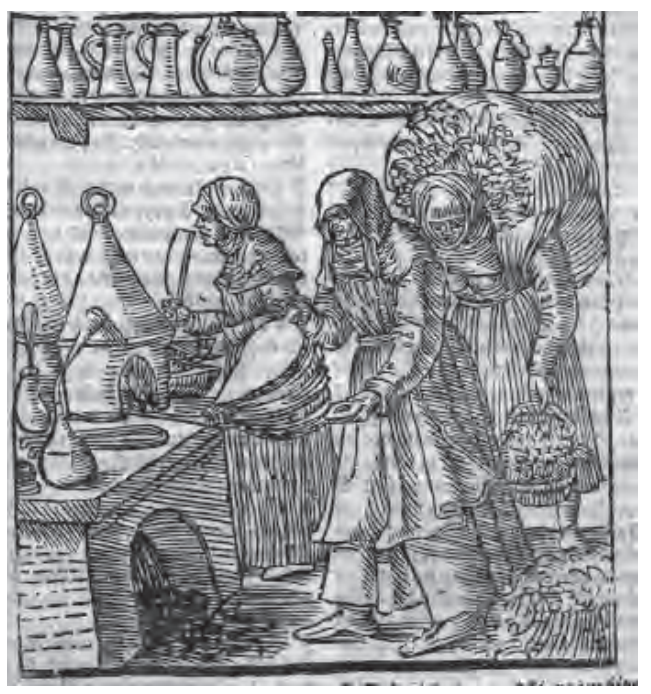

Ryc. 6. Drzeworyt przedstawiający destylację tzw. wódek ziołowych (Źródło: Falimirz 1534) 

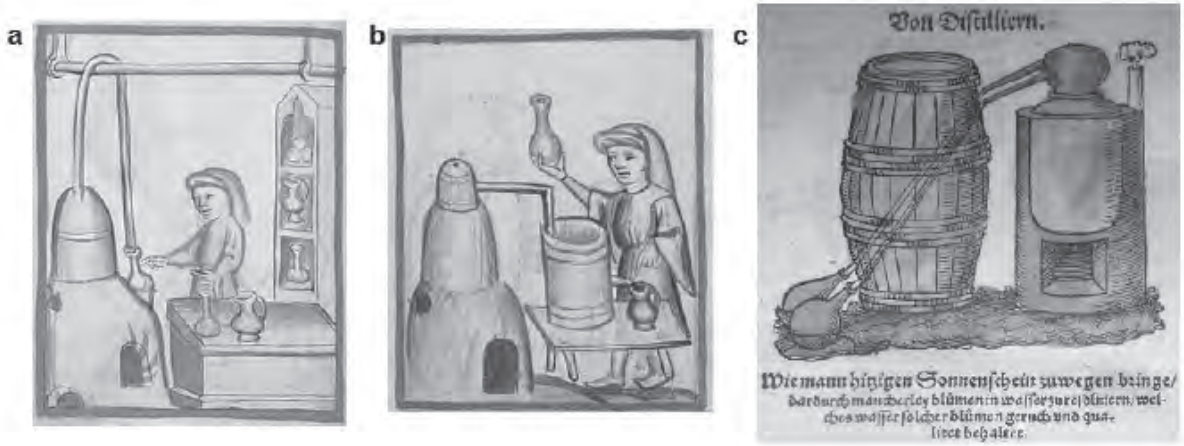

Ryc. 7. Alembiki z systemem zewnętrznego chłodzenia: a - urządzenie destylujące z giętką rurnica, $\mathrm{b}$ - urządzenie destylujące $\mathrm{z}$ zewnętrzną chłodnicą umieszczoną $\mathrm{w}$ beczce $\mathrm{z}$ wodă, $\mathrm{c}$ - urządzenie destylujące z zewnętrzną chłodnicą umieszczoną $\mathrm{w}$ beczce $\mathrm{z}$ wodą, skorelowane ze specjalnym piecem do balneum Mariae

(Źródło: a, b - Hartlieb 1411; c - Lonicer 1572)

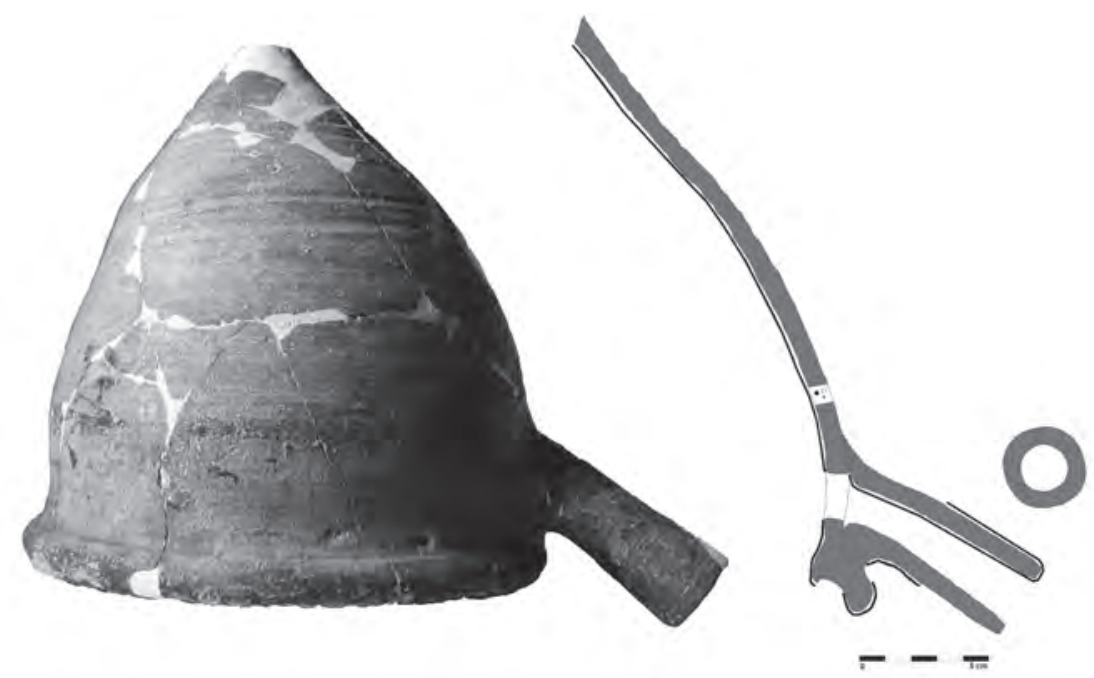

Ryc. 8. Ceramiczny alembik z zamku w Pucku (Źródło: oprac. materiału i fot. M. Szymański, rys. E. Czwal) 